\title{
Epidemiology of childhood injuries in Saudi Arabia: a scoping review
}

\author{
Hadeel Albedewi ${ }^{1}$, Nouf Al-Saud ${ }^{2}$, Abdulhameed Kashkary ${ }^{3}$, Ada Al-Qunaibet ${ }^{3}$, Salem M. AlBalawi ${ }^{3}$ and \\ Suliman Alghnam ${ }^{4}$
}

\begin{abstract}
Background: Injury is the leading cause of death among Saudi children. Despite that, much remains unknown on the epidemiology and the extent of burden. This scoping review aims to describe previous literature on injury burden, including types, causes, and outcomes.

Methods: We conducted a scoping literature search of English published articles on injuries among Saudi children between 0 to 18 years old using Scopus, MEDLINE, and Web of Science between January 2000 and December 2020. The primary outcome was the type and the cause of childhood injuries. Data extraction was based on specified data elements that included study characteristics and epidemiological parameters. The STROBE checklist was used to assess the quality of publications.

Results: The initial review identified 3,384 studies. Of which, 36 studies met the inclusion criteria. A total of 20,136 children were included; of them, $69 \%$ were males. Among studies that examined overall injuries, falls represented $31.9 \%$, while $25.1 \%$ were due to Motor Vehicle Collision (MVC). The leading cause of fractures was falls (37.9\%), followed by MVC (21.5\%). The leading cause was flames (52.1\%) followed by scald (36.4\%) for burns. While for poisoning, medications were the leading cause of (39.9\%), followed by toxic household products (25.7\%). Weighted mortality rates were $5.2 \%$ for overall injuries, $8.3 \%$ for fractures of the skull and spine, and $17.4 \%$ for burns.
\end{abstract}

Conclusions: MVC and falls are associated with the highest share of injuries in the kingdom. These findings can guide prevention efforts to reduce injury burden and improve population health. Further population-based research is warranted to explore the determinants of childhood injuries across all regions of Saudi Arabia.

Keywords: Unintentional injuries, Fractures, Burns, Road traffic, Poisoning, Oral injuries

\section{Background}

Injuries are the leading cause of morbidity and mortality worldwide [1]. According to the Global Burden of Disease (GBD) study, 973 million individuals suffer from injuries that require medical attention, and around 4.8 million die every year [2]. Childhood injuries are of particular concern. In 2011, more than 630,000 children died because

\footnotetext{
*Correspondence: ghnams@ngha.med.sa

${ }^{4}$ Population Health Section-King Abdullah International Medical

Research Center, King Saud bin Abdulaziz University for Health Sciences,

Riyadh, Saudi Arabia

Full list of author information is available at the end of the article
}

of injuries [3]. In the United States, unintentional injuries were the leading cause of death in 2019 [4]. According to the Centers for Disease Control and Prevention (CDC), the leading cause of death from unintentional injuries was MVC followed by drowning, burns, and suffocation, whereas unintentional fall remains the most common cause for nonfatal injuries.

The burden of injuries is not limited to preventable deaths. Millions of children require hospitalization, and some endure lifelong disabilities that could negatively affect their stages of development. According to a report by the World Health Organization (WHO), loss 
of Disability-Adjusted Life Years (DALYs) worldwide is predicted to be primarily caused by MVC by 2030 [5]. Around $16.6 \%$ of loss DALYs among children in Saudi Arabia are due to injuries and of which $8.1 \%$ are due to MVC [6].

Injuries are not random events, but they are often associated with predictable factors. Age is associated with a higher risk of serious injury [7]. A previous systematic review suggested a bimodal distribution peaking at the two opposite age extremities [7]. Teenagers between 15 to 19 have an increased risk due to increased exposure to hazards and risk-taking behaviours. On the other hand, young infants are also at a high risk of injuries [7]. Gender also plays a role in the risk of fatal and nonfatal injuries among children [7]. Although males are at a higher risk for mortality due to all types of injury, the male to female ratio varies by the cause of injury. For example, motorcycle crashes, falls, and firearm-related deaths are ten times higher among males, while pedestrian-related deaths are only slightly greater among males $[7,8]$.

Child injuries are a public health concern for both high-income and low-income countries but more pronounced in countries undergoing extreme urbanization and industrialization $[9,10]$. However, the risk of injuryrelated deaths is higher among low- and middle-income than high-income countries [11]. Children of low- and middle-income countries are exposed to more hostile environments; open fires, unstable construction sites, unprotected stairways, absence of safe play space, and lack of safe storage of chemicals [12]. Poverty is a risk factor for unintentional injuries even within high-income countries [13].

In Saudi Arabia, two injuries were ranked among the ten leading causes of death: transport injuries and unintentional injuries, according to the GBD [14]. The majority of preventable deaths in Saudi children (82.5\%) were attributed to injuries [15]. The leading cause for injury mortality was MVC at $60.6 \%$ and was most commonly found among 13-18-year-olds, followed by drowning at $13.4 \%$ and most commonly found among 6-12-year-olds [15].

Approximately 31\% of the Saudi population are children and adolescents [14]. Therefore, the consequences of injuries will have direct effects on population health. Despite that, limited and fragmented exploration of the burden of childhood injuries may negatively impact prevention. Further understanding of the epidemiology of child injuries will facilitate efforts in prevention and guide future research to understand the magnitude of the problem. Therefore, we aim in this review to describe the magnitude of childhood injuries, including the most common types and causes across gender and age groups in Saudi Arabia.

\section{Methods}

Search strategy and study selection:

A literature search was performed in January 2021 using Scopus, MEDLINE, and Web of Science for any study published in English between January 2000 and December 2020. We used search limits for source type, document type, year, language, country, and age. The search strategy for each database is detailed in Supplementary file 1. Additional records were identified from reference lists of selected articles, Saudi digital library, and search engines. One reviewer (H.A) reviewed titles and abstracts to assess relevance and collected relevant titles and abstracts for full text assessment. Deduplication was performed using Microsoft Excel. Full text manuscripts were reviewed and evaluated against the eligibility criteria.

\section{Eligibility criteria}

The databases were searched from April to May 2021 to identify articles published between January 1st, 2000, to December 31st, 2020. The timeframe was chosen because medical documentation and research in Saudi Arabia became mature only in the last two decades. The steps we followed for study selection are shown in (Fig. 1). To be included in this review, a study had to meet the following criteria:

1) Children (between 0 to 18 years of age.).

2) The publication date is between 2000 and 2020.

3) Published in English.

4) Contain epidemiological data such as age and gender.

5) Focused on injuries including drowning, fall, trauma, fracture, burn, MVC, poisoning, and suffocation.

Exclusion criteria were:

1)Reviews, case studies, or abstracts.

2)Sample size of fewer than 50 children.

\section{Type of studies}

The type of studies included was retrospective and prospective cohorts in addition to cross-sectional studies.

\section{Data extraction and synthesis}

The primary outcome was the type and the cause of childhood injuries and their distribution among age groups, gender, and regions. The number of children, year of publication, study timeframe, study type, region, age, gender, type and cause of injury, and mortality rate were recorded by one reviewer (H.A). No authors have been contacted to obtain any additional data. After reviewing the literature, studies were categorized based on the type of injury into six categories: overall injuries, 


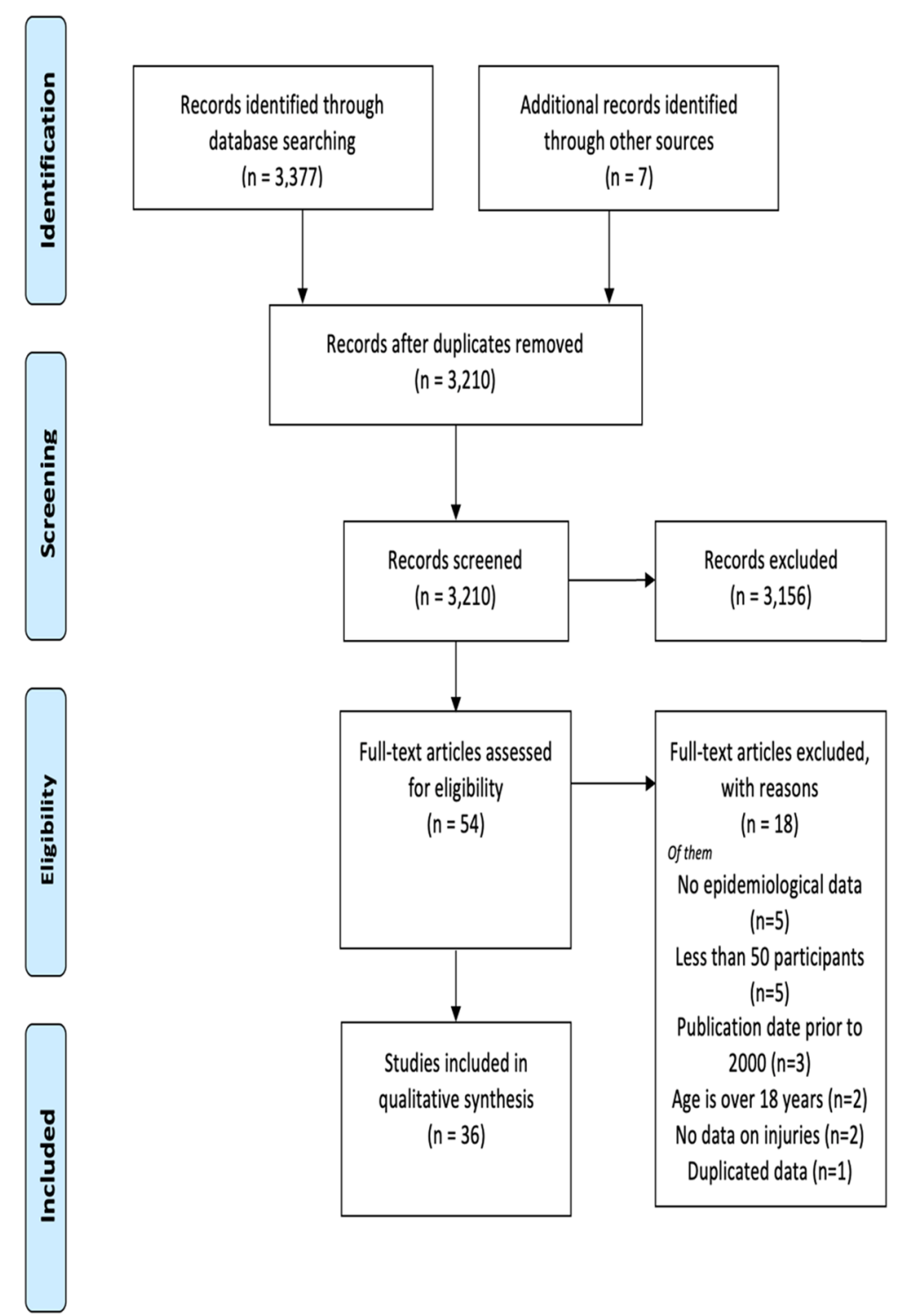

Fig. 1 PRISMA flow diagram of articles screening and selection

fractures, burns, MVC injuries, oral injuries, and poisoning. Weighted percentages were calculated for gender, causes, and mechanism of injury in addition to the reported overall mortality rate in each category.

\section{Quality assessment}

The quality of studies was assessed by two independent reviewers (HA and NA) using the Strengthening the Reporting of Observational Studies in Epidemiology (STROBE) statement [16]. The STROBE checklist includes 22 items distributed as 1 for abstract, 2 for introduction, 9 for the methods, 5 for the results, and 4 for the discussion, and 1 for funding. Disagreements were resolved by consensus.

\section{Results}

The initial search identified 3,384 studies. After screening titles and abstracts, 3,330 publications were excluded for being irrelevant or duplicates. The full text of 54 studies was assessed for eligibility, where 18 did not meet the inclusion criteria and were excluded. Thirty-six studies have met the inclusion criteria and were included in this scoping review (Fig. 1). In total, 20,136 participants were included. Of the total population, 13,890 were males (69\%), and 5,596 were females (27.8\%), while gender was 
not reported for 650 children (3.2\%). Twenty-one studies were conducted in the central region - Riyadh, which accounts for the majority (58\%) of the studies. As for the remaining studies, five were conducted in the eastern region, four, three, and one were conducted in the western region, Southern region, and Northern region, respectively. Two studies were conducted in several regions of the country.

Of the included publications, eleven studies explored overall injuries. Five studies focused on fractures, five on burns, four on MVC injuries, four on oral injuries, and seven examined poisoning. A visual summary of some of the studies' findings is presented in Fig. 2. Based on the STROBE checklist, the quality of studies ranged from 5 to 19 , with the majority scores being between 13 and 16 (Supplementary file 2). The most common missing items were the explanation of the study size, variables, handling quantitative variables, controlling for bias, and generalizability.

\section{Overall injuries}

Eleven thousand six hundred seventy-five participants were included in the overall injuries' category (Table 1) [17-27]. Most injured children were males (74.6\%). In fact, gender was found to be a significant predictor of unintentional injuries, falls and MVC with higher odds for males (OR: 2.59, OR: 1.76, OR: 2.17 , respectively, $P$ $<0.01)[17,26]$. According to a household survey conducted among 1,650 participants, $22 \%$ of children sustained an injury in the past year [17]. A more recent study with a smaller sample $(n=283)$ suggested that the prevalence of unintentional childhood injuries was $24.7 \%$ in the past 12 months [26]. The weighted percentage of falls accounted for $31.9 \%$ of overall injuries, followed by MVC representing 25.1\%. Head injuries were most likely to be associated with MVC followed by falls [18]. Furthermore, blunt injuries caused by falls and MVC were the leading cause of deaths in overall injuries [21]. Additionally, MVC was reported to be the primary cause of injury that led to an extended length of stay [22]. In fact, the mechanism of injury was found to be a significant predictor of extended length of stay with higher odds for MVC and burns (OR: 16.2, OR: 14.5, respectively, $P<$ 0.001 ) as opposed to falls [22].

Another critical childhood injury was drowning. A study showed that males represented $66.7 \%$ of the drowning incidents. Among this population, drowning led to brain death (4\%), and $2 \%$ of victims sustained

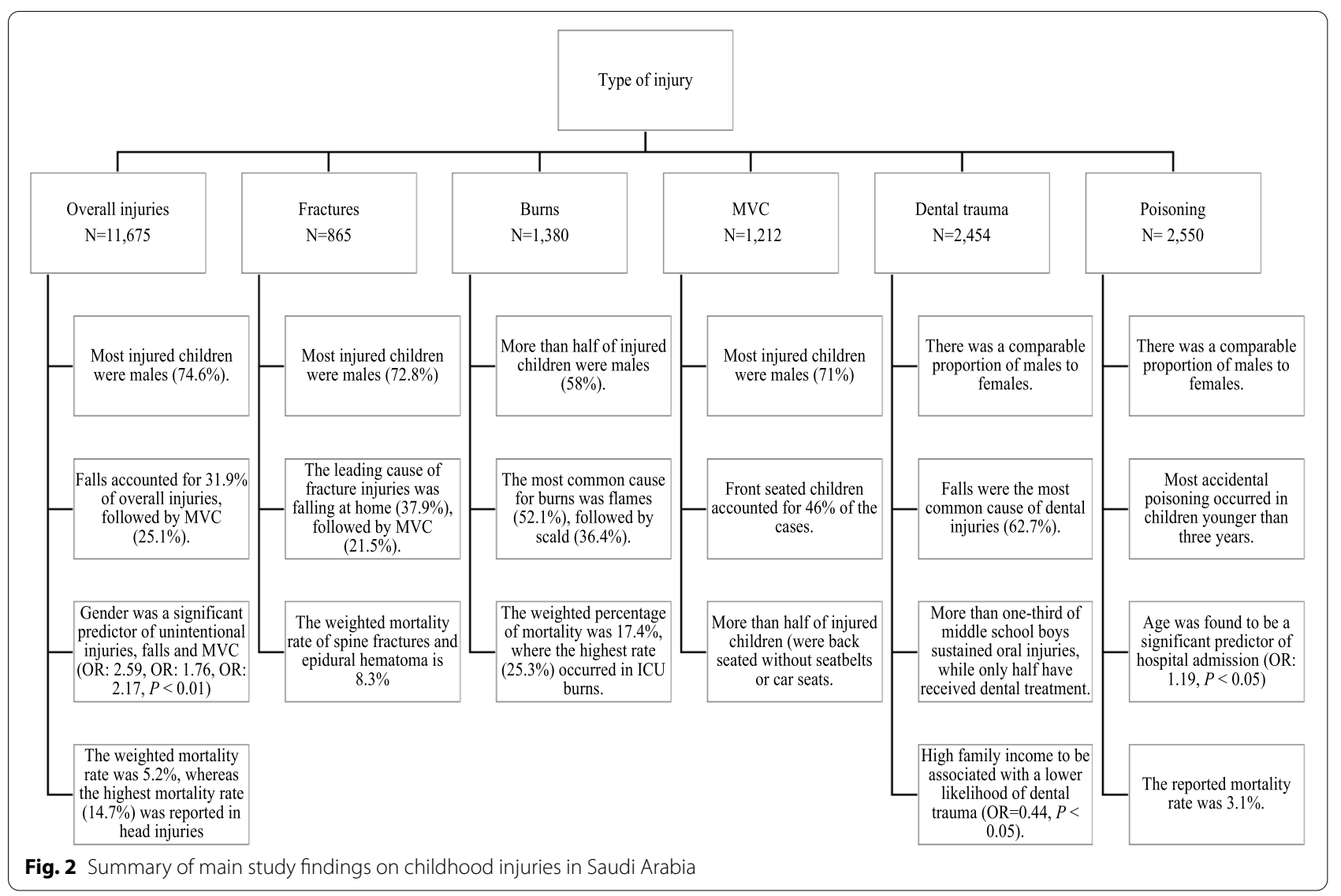


Table 1 Study characteristics and relevant findings of studies of childhood overall injuries

\begin{tabular}{|c|c|c|c|c|c|}
\hline Author & Timeframe & Study type (sample size) & Relevant findings & Region & STROBE Score \\
\hline (Gad et al., 2011) [17] & 2011 & $\begin{array}{l}\text { Cross-sectional } \\
N=1650\end{array}$ & $\begin{array}{l}\text { History of injury in the past } \\
12 \text { months was reported by } \\
22.2 \% \text { of the children. } \\
\text { Injuries were higher among } \\
\text { males compared to females } \\
\text { ( } 26 \% \text { vs. } 18 \% \text {, respectively, } P \\
<0.001) \text {. } \\
\text { Male gender was a significant } \\
\text { predictor of falls and MVC (OR: } \\
1.76, \text { OR: } 2.17 \text {, respectively, } P \\
<0.001) \\
\text { The most common type of } \\
\text { injury fall ( } 40.4 \%) \text { followed by } \\
\text { MVC (15\%) and food poison- } \\
\text { ing ( } 8.8 \%) \text {. } \\
\text { The reported mortality rate of } \\
\text { injured children was } 1.5 \%\end{array}$ & Riyadh & 17 \\
\hline (Alhabdan et al., 2013) [18] & $2001-2009$ & $\begin{array}{l}\text { Retrospective } \\
\mathrm{N}=1219\end{array}$ & $\begin{array}{l}\text { The most common cause } \\
\text { of injury was MVC ( } 34.2 \%) \\
\text { followed by pedestrian injury } \\
\text { ( } 30.3 \% \text { ) and falls }(28.4 \%) \text {. } \\
\text { Most of head injuries (66.3\%) } \\
\text { occurred in children younger } \\
\text { than } 12 \text { years. } \\
\text { The overall mortality rate was } \\
14.7 \% \text {. }\end{array}$ & Riyadh & 14 \\
\hline (Alanzi, 2013) [19] & $2010-2011$ & $\begin{array}{l}\text { Retrospective } \\
N=200\end{array}$ & $\begin{array}{l}\text { The prevalence of fingertip } \\
\text { injury was significantly higher } \\
\text { among males compared to } \\
\text { females (( } 59.5 \% \text { vs. } 40.5 \% \text {, } \\
P<0.001) \text {. } \\
\text { Children younger than } 5 \\
\text { years were more likely to have } \\
\text { fingertip incidents. } \\
\text { The most common cause for } \\
\text { fingertip injury was house } \\
\text { doors. }\end{array}$ & Riyadh & 13 \\
\hline (Assiry, 2014) [20] & $2012-2014$ & $\begin{array}{l}\text { Retrospective } \\
\mathrm{N}=71\end{array}$ & $\begin{array}{l}\text { Head injuries were most likely } \\
\text { to occur in males }(76.1 \%) \text {. } \\
\text { The major cause was MVC } \\
(63.4 \%) \text { followed by falls } \\
(32.4 \%) \text {. }\end{array}$ & Southern region - Asir & 13 \\
\hline (Alnasser et al., 2018) [21] & $2009-2014$ & $\begin{array}{l}\text { Retrospective } \\
N=1762\end{array}$ & $\begin{array}{l}\text { Males represented } 68.4 \% \text { of } \\
\text { admitted children following } \\
\text { injuries. } \\
\text { The most common type of } \\
\text { injury was blunt trauma ( } 73 \%) \text {, } \\
\text { followed by burns (17\%) and } \\
\text { penetrating injuries ( } 10 \%) \text {. } \\
\text { Blunt trauma was mainly } \\
\text { caused by MVC (50\%) followed } \\
\text { by fall ( } 40 \%) \text {. } \\
\text { The leading cause of deaths } \\
\text { among patients was blunt } \\
\text { injury (92\%). } \\
\text { The mortality rate was } 2.8 \%\end{array}$ & Riyadh & 16 \\
\hline
\end{tabular}


Table 1 (continued)

\begin{tabular}{|c|c|c|c|c|c|}
\hline Author & Timeframe & Study type (sample size) & Relevant findings & Region & STROBE Score \\
\hline (Alghnam et al., 2019) [22] & $2001-2018$ & $\begin{array}{l}\text { Retrospective } \\
N=5563\end{array}$ & $\begin{array}{l}\text { Males represented } 75.8 \% \text { of } \\
\text { admitted children following } \\
\text { injuries. } \\
\text { The most common type of } \\
\text { injury was fall ( } 31.5 \%) \text {, fol- } \\
\text { lowed by an MVC ( } 28.5 \%) \\
\text { The prevalence of children } \\
\text { who had extended length of } \\
\text { stay was } 14 \% \text {. } \\
\text { The major cause of injury that } \\
\text { led to extended length of stay } \\
\text { was MVC. } \\
\text { Mechanism of injury was a sig- } \\
\text { nificant predictor of extended } \\
\text { length of stay with higher } \\
\text { odds for MVC and burns (OR: } \\
16.2, \text { OR: } 14.5 \text {, respectively, } P< \\
0.001) \text { as opposed to falls. }\end{array}$ & Riyadh & 19 \\
\hline (Al-Qurashi et al., 2019) [23] & $2005-2015$ & $\begin{array}{l}\text { Retrospective } \\
\mathrm{N}=51\end{array}$ & $\begin{array}{l}\text { Males represented } 66.7 \% \text { of } \\
\text { the drowning incidents. } \\
\text { Brain death occurred in } 4 \% \\
\text { of the cases, } 2 \% \text { had severe } \\
\text { neurological issues and } 94 \% \\
\text { fully recovered. } \\
\text { Most cases }(74.5 \%) \text { occurred } \\
\text { in the sea ( } 56.9 \% \text { ) at the night } \\
\text { with no lifeguard present } \\
(92.2 \%) \text {. }\end{array}$ & Eastern Region -Dammam & 15 \\
\hline (Alzamil et al., 2019) [24] & 2018 & $\begin{array}{l}\text { Cross-sectional } \\
\mathrm{N}=323\end{array}$ & $\begin{array}{l}\text { Visual loss was present in 39\% } \\
\text { of Pediatric Ophthalmology } \\
\text { Clinic ( } N=818) \text { whereas } 22.9 \% \\
\text { were blind. } \\
\text { Trauma was the most com- } \\
\text { mon cause for unilateral } \\
\text { blindness (20.7\%) followed by } \\
\text { refractive errors (15.5\%). }\end{array}$ & Eastern region - Dhahran & 15 \\
\hline (AlAteeq et al., 2020) [25] & $2016-2017$ & $\begin{array}{l}\text { Cross-sectional } \\
\mathrm{N}=491\end{array}$ & $\begin{array}{l}\text { Most injuries occurred in } \\
\text { males (64\%). } \\
\text { The leading cause of injuries } \\
\text { was fall ( } 47.7 \%) \text { followed by } \\
\text { hot liquids and chemical } \\
\text { exposure (14.5\%). } \\
\text { The most common injury } \\
\text { types were fractures, disloca- } \\
\text { tions, and subluxations ( } 47.3 \%) \\
\text { followed by penetration } \\
\text { injuries ( } 21 \% \text { ) and burn injuries } \\
\text { (17.5\%). } \\
\text { The mortality rate was } 1.2 \%\end{array}$ & Riyadh & 15 \\
\hline
\end{tabular}


Table 1 (continued)

\begin{tabular}{|c|c|c|c|c|c|}
\hline Author & Timeframe & Study type (sample size) & Relevant findings & Region & STROBE Score \\
\hline $\begin{array}{l}\text { (Alkhamis \& Abdulkader, 2020) } \\
\text { [26] }\end{array}$ & 2020 & $\begin{array}{l}\text { Cross-sectional } \\
\mathrm{N}=283\end{array}$ & $\begin{array}{l}\text { The prevalence of uninten- } \\
\text { tional childhood injuries was } \\
24.7 \% \text { in the past } 12 \text { months. } \\
\text { The prevalence of uninten- } \\
\text { tional childhood injuries } \\
\text { was significantly higher in } \\
\text { males compared to females } \\
(32.5 \% \text { vs. } 15.9 \% \text {, respectively, } \\
P=0.001) \text {. } \\
\text { Male gender was a significant } \\
\text { predictor of unintentional } \\
\text { injuries (OR: } 2.59, P=0.003) \text {. } \\
\text { Most injuries occurred at } \\
\text { home }(74.3 \%) \text {. } \\
\text { The most common cause of } \\
\text { injurie was falls }(62.9 \%) \text { fol- } \\
\text { lowed by burns }(22.9 \%) \text {. }\end{array}$ & Riyadh & 18 \\
\hline (Al-Sarheed et al., 2020) [27] & $2005-2018$ & $\begin{array}{l}\text { Retrospective } \\
\mathrm{N}=62\end{array}$ & $\begin{array}{l}\text { Most trauma injuries occurred } \\
\text { in males ( } 77.4 \%) \text {. } \\
\text { The most common cause of } \\
\text { injury was MVC ( } 59.7 \%) \text {, fol- } \\
\text { lowed by pedestrian accidents } \\
\text { ( } 21 \% \text { ) and falls ( } 14.5 \%) \text {. } \\
\text { The mortality rate was } 12.7 \%\end{array}$ & Riyadh & 15 \\
\hline
\end{tabular}

MVC Motor Vehicle Collision, OR Odds ratio

severe neurological damage [23]. The study, which was conducted in the eastern region, reported that most cases occurred in the sea $(74.5 \%)$ at night (56.9\%) with no lifeguard present (92.2\%).

Fingertip injuries were identified as one mechanism and were significantly higher among males (59.5\%) compared to females [19]. These injuries were commonly caused by house doors and more prevalent among children younger than five years. Overall, the mortality rate for overall injuries was only reported in five studies. Among those studies, the weighted mortality rate was $5.2 \%$, whereas the highest mortality rate $(14.7 \%)$ was reported in head injuries [18].

\section{Fractures}

Fracture injuries studies included 865 participants (Table 2) [28-32]. The majority of reported fractures occurred among males (72.8\%). The ratio of male to female was 2.68:1. The leading cause of fracture injuries was falling at home (37.9\%), followed by MVC (21.5\%). Other causes for fractures included door slams, direct hits, and pedestrian injuries. Fractures occurred mainly among older children as close half of children were between 13-18 of age [30]. At the same time, epidural hematoma was more likely to occur among children between 5-14 years of age than other children [29, 31]. On the other hand, nonaccidental fractures were more common in preschoolers, followed by infants [32]. The mortality rate was reported in two studies conducted on spine fractures and epidural hematoma, both with a rate of $8.3 \%[29,31]$.

\section{Burns}

Burn studies included 1,380 children (Table 3) [33-37]. Of those, $58 \%$ were males. The extent of burns was minor in most cases (less than $20 \%$ of Total Body Surface Area (TBSA)). The most common cause for burns was flames (52.1\%), followed by scald (36.4\%). Two studies showed that most burns $(60 \%)$ occurred among toddlers and preschoolers [33, 34]. About half of the victims admitted to the Intensive Care Unit (ICU) were between 5-10 years of age [36]. Four studies have reported mortality rates; the weighted percentage of mortality was $17.4 \%$, where the highest rate $(25.3 \%)$ occurred among those admitted to the ICU.

\section{MVC}

One thousand two hundred twelve children were included in the MVC studies (Table 4) [38-41]. Overall, males represented the majority $(71 \%)$ of injured victims. One study showed that most injuries (71\%) were sustained by pedestrians, followed by passengers (27\%) [38]. Front seated children accounted for $46 \%$ of the cases with a higher rate of isolated head, neck, or facial injuries than back seated children $(51.2 \%$ vs. $25 \%, P=$ 0.01 ) [39]. On the other hand, children seated in the back had higher rates of rollover $(52.1 \%$ vs $24.4 \%, P=$ $0.02)$, ejection ( $41.7 \%$ vs $22 \%, P=0.05)$, and occupant 
Table 2 Study characteristics and relevant findings of studies of childhood fractures

\begin{tabular}{|c|c|c|c|c|c|}
\hline Author & Timeframe & Study type (sample size) & Relevant findings & Region & STROBE Score \\
\hline (Alomran et al., 2012) [28] & $2004-2009$ & $\begin{array}{l}\text { Retrospective } \\
\mathrm{N}=254\end{array}$ & $\begin{array}{l}\text { Most fractures occurred in males (62.6\%). } \\
\text { Almost half of injuries ( } 48.8 \%) \text { occurred at home. } \\
\text { The major cause of injury was fall at home } \\
(48.8 \%) \text { followed by motor vehicle accidents } \\
(29.52 \%)\end{array}$ & Riyadh & 13 \\
\hline (Al-Habib et al., 2014) [29] & $2001-2009$ & $\begin{array}{l}\text { Retrospective } \\
\mathrm{N}=120\end{array}$ & $\begin{array}{l}\text { The majority of injured children were males } \\
(83.3 \%)(P=0.003) \text {. } \\
\text { The major cause of spine injury was MVC (60.8\%) } \\
\text { followed by pedestrian injuries ( } 20.8 \%) \text {, fall- } \\
\text { related injuries (15\%). } \\
\text { Traumatic spine fractures were more common in } \\
\text { children age between } 16-18 \text { years. } \\
\text { The mortality rate was } 8.3 \% \text {. }\end{array}$ & Riyadh & 16 \\
\hline (Al-Jasser et al., 2015) [30] & $2005-211$ & $\begin{array}{l}\text { Retrospective } \\
\mathrm{N}=361\end{array}$ & $\begin{array}{l}\text { The majority of fractures occurred in males } \\
(80.6 \%)(P<0.0001) \text {. } \\
\text { Injured children were most likely }(46.2 \%) \text { to be } \\
\text { between } 13-18 \text { of age. } \\
\text { The major cause of injury was fall at home } \\
(35.7 \%) \text { followed by door slam }(25 \%) \text { and sport } \\
\text { related }(17.1 \%) \text {. }\end{array}$ & Riyadh & 16 \\
\hline (Umerani et al., 2018) [31] & $2012-2014$ & $\begin{array}{l}\text { Retrospective } \\
\mathrm{N}=72\end{array}$ & $\begin{array}{l}\text { Epidural hematoma was most likely to occur in } \\
\text { males (65.3\%) and in age between } 5-14 \text { years. } \\
\text { The most common cause for epidural hematoma } \\
\text { was MVC ( } 52.8 \%) \text { followed by falls ( } 34.7 \%) \text {. } \\
\text { The mortality rate was } 8.3 \% \text {. }\end{array}$ & $\begin{array}{l}\text { Eastern } \\
\text { region - } \\
\text { Dammam }\end{array}$ & 11 \\
\hline (Jawadi et al., 2019) [31] & $2009-2015$ & $\begin{array}{l}\text { Retrospective } \\
\mathrm{N}=58\end{array}$ & $\begin{array}{l}\text { Nonaccidental fractures were most likely to occur } \\
\text { in males (59\%) and preschoolers ( } 45 \%) \text { followed } \\
\text { by infants (34\%). } \\
\text { The rate of hospital admission was } 70 \% \text {. } \\
\text { Physical abuse accounted for } 44.6 \% \text { of the inci- } \\
\text { dents whilst } 51.8 \% \text { was due to neglect. } \\
\text { The most common type of injury was fall (54.8\%) } \\
\text { followed by direct hit ( } 26.1 \%) \text {. }\end{array}$ & Riyadh & 16 \\
\hline
\end{tabular}

death ratio ( $14.8 \%$ vs $4 \%, P=0.04)$ and were more likely to have long bone or pelvic fractures $(60.4 \%$ vs $36.6 \%$, $P=0.02$ ) [39]. Moreover, a study showed that $38.3 \%$ of children injured in MVC sustained head injuries, whereas facial injuries were sustained by $34.8 \%$ of children [41]. According to that study, 2.4\% lost their lives due to the MVC. More than half of injured children (53.8\%) were back seated without seatbelts or car seats, while $9.1 \%$ were driving [41].

\section{Oral and dental trauma}

The number of patients included in oral and dental trauma studies was 2,454 (Table 5) [42-45]. There was a comparable proportion of males to females [43, 44]. While the other two were conducted solely in males [42, $45]$. Falls were the most common cause of dental injuries $(62.7 \%)[43,44]$. More than one-third $(39.5 \%)$ of middle school boys sustained oral injuries, while only half have received dental treatment [45]. The same study showed high family income to be associated with a lower likelihood of dental trauma $(\mathrm{OR}=0.44, P<0.05)$ [45].

\section{Poisoning and toxicological exposure}

Studies on childhood poisoning and toxicological exposure included 2,550 children (Table 6) [46-52]. Most of the accidental poisoning occurred among children younger than three years. Further, age was found to be a significant predictor of hospital admission (OR: 1.19, $\mathrm{P}<0.05)$ [48]. The male-female ratio was comparable (1.17:1). The most common mechanism was ingestion with drugs associated with $39.9 \%$ of the cases, followed by toxic household products $(25.7 \%)$. One study reported that no action was taken by parents $(90.2 \%)$ following the incidents [47]. A study conducted in several regions of the kingdom reported a $3.1 \%$ mortality rate [51].

\section{Discussion}

This scoping review suggests that falls and MVC are the leading causes of injuries in the kingdom. Similarly, a global study conducted in low-and middle-income countries found fall and MVC to be the most common mechanism of childhood injuries [53]. 
Table 3 Study characteristics and relevant findings of studies of childhood burns

\begin{tabular}{|c|c|c|c|c|c|}
\hline Author & Timeframe & Study type (sample size) & Relevant findings & Region & STROBE Score \\
\hline $\begin{array}{l}\text { (Priyadarshini \& Kumar, 2015) } \\
\text { [33] }\end{array}$ & $2007-2011$ & $\begin{array}{l}\text { Retrospective } \\
\mathrm{N}=100\end{array}$ & $\begin{array}{l}\text { Most burns occurred in chil- } \\
\text { dren younger than } 6 \text { years of } \\
\text { age }(59 \%) \text {. } \\
\text { Comparable proportions } \\
\text { of male and female injured } \\
\text { children ( } 51 \text { vs. } 49 \% \text {, respec- } \\
\text { tively). } \\
51 \% \text { had minor burns ( } 0-20 \% \\
\text { TBSA). } \\
\text { Cause of burn was } 47 \% \text { scald } \\
\text { and } 42 \% \text { flame. } \\
\text { Overall mortality: } 15 \%\end{array}$ & $\begin{array}{l}\text { Northern region - Sakaka, } \\
\text { Al Jouf, }\end{array}$ & 12 \\
\hline (Alharthy et al., 2016) [33] & 2013 & $\begin{array}{l}\text { Retrospective } \\
N=148\end{array}$ & $\begin{array}{l}\text { More than half of burn inju- } \\
\text { ries }(54 \%) \text { occurred in male } \\
\text { children. } \\
\text { The mean TBSA was 5\%. } \\
\text { Most of burns occurred in } \\
\text { toddlers and preschoolers } \\
\text { (80\%). } \\
\text { Scald burns were the most } \\
\text { common type of burn } \\
(76.4 \%) \text { followed by flame } \\
\text { (15.5\%). } \\
\text { No reported deaths. }\end{array}$ & Riyadh & 16 \\
\hline (Alturki et al., 2019) [35] & $2011-2016$ & $\begin{array}{l}\text { Retrospective } \\
\mathrm{N}=95\end{array}$ & $\begin{array}{l}\text { More than half of injured } \\
\text { children were males (56.8\%). } \\
\text { Most burn cases were infants, } \\
\text { toddlers, and preschoolers } \\
\text { ( } 72.5 \%) \text {. } \\
\text { Scald burn was the most } \\
\text { common type of burn } \\
\text { (68.8\%). }\end{array}$ & Western region - Jeddah & 16 \\
\hline (Akkam et al., 2020) [36] & $2009-2018$ & $\begin{array}{l}\text { Retrospective } \\
\mathrm{N}=787\end{array}$ & $\begin{array}{l}\text { Slightly higher male victims } \\
\text { than females (56.4 vs. } 43.6 \% \text { ). } \\
\text { Most injuries ( } 73.8 \%) \\
\text { occurred at home. } \\
\text { Almost half of subjects } 52 \% \\
\text { had minor burn (10-19\% } \\
\text { TBSA) } \\
\text { The main cause of injury was } \\
\text { flame (81\%). } \\
\text { Overall mortality: } 25 \%\end{array}$ & Riyadh & 17 \\
\hline (Mater et al., 2020) [37] & $2016-2017$ & $\begin{array}{l}\text { Retrospective } \\
N=250\end{array}$ & $\begin{array}{l}\text { Higher proportion of burns } \\
\text { among males compared } \\
\text { to females ( } 68 \% \text { vs. } 32 \% \text {, } \\
\text { respectively). } \\
\text { The mean TBSA was } 16.54 \% \\
\text { Scald was the major cause of } \\
\text { burn ( } 63.4 \%) \text {. } \\
\text { Overall mortality: } 4.8 \%\end{array}$ & Riyadh & 12 \\
\hline
\end{tabular}

TBSA Total Body Surface Area

Many MVC injuries are preventable using evidencebased safety measures such as seatbelts, car seats, or helmets. However, they remain a neglected focus in the kingdom. In this respect, a study conducted in 2018 to assess the use of child restraint systems found that only one-third of the families reported having child restraint systems while only half of them were consistently using them [54]. Additionally, more than half of the families reported setting children on the passenger's lap [54]. Therefore, further investment in public health interventions to reduce falls and MVC is warranted to reduce their burden on population health.

Our findings show that males represented most overall injuries, fractures, burns, MVC, and dental trauma. These results are consistent with the public data obtained from the CDC, stating that males accounted for $58.4 \%$ of 
Table 4 Study characteristics and relevant findings of studies of childhood MVC injuries

\begin{tabular}{|c|c|c|c|c|c|}
\hline Author & Timeframe & Study type (sample size) & Relevant findings & Region & STROBE Score \\
\hline (Crankson, 2006) [38] & $1994-2003$ & $\begin{array}{l}\text { Retrospective } \\
\mathrm{N}=664\end{array}$ & $\begin{array}{l}\text { Males represented } 71 \% \text { of MVC } \\
\text { injuries } \\
\text { MVC injuries represented } 42 \% \\
\text { of pediatric trauma admissions. } \\
\text { Mechanism of injury was } 71 \% \\
\text { pedestrians, } 27 \% \text { auto passen- } \\
\text { gers, } 1.5 \% \text { bicyclists and } 0.5 \% \\
\text { motorcyclists. }\end{array}$ & Riyadh & 12 \\
\hline (Al-Jazaeri et al., 2012) [39] & $2001-2010$ & $\begin{array}{l}\text { Retrospective } \\
\mathrm{N}=89\end{array}$ & $\begin{array}{l}\text { Boys represented } 72 \% \text { of MVC } \\
\text { injuries } \\
\text { Injured children were front } \\
\text { seated in } 46 \% \text { of the cases. } \\
\text { Front seated children had } \\
\text { higher rate of isolated head, } \\
\text { neck or facial injuries ( } 51.2 \% \text { vs } \\
25 \%, P=.01 \text { ) } \\
\text { Back seated children had } \\
\text { higher rates of rollover ( } 52.1 \% \\
\text { vs } 24.4 \%, P=.02) \text {, ejection } \\
(41.7 \% \text { vs } 22 \%, P=.05) \text {, and } \\
\text { occupant death ratio ( } 14.8 \% \\
\text { vs } 4 \%, P=.04 \text { ) and were more } \\
\text { likely to have long bone or pel- } \\
\text { vic fractures ( } 60.4 \% \text { vs } 36.6 \% \text {, } \\
P=.025) \text {. }\end{array}$ & Riyadh & 9 \\
\hline $\begin{array}{l}\text { (Mohmmedthani et al., 2018) } \\
\text { [40] }\end{array}$ & $2011-2016$ & $\begin{array}{l}\text { Retrospective } \\
\mathrm{N}=206\end{array}$ & $\begin{array}{l}\text { Most of the cases }(72.5 \%) \text { were } \\
\text { younger than } 10 \text { years. } \\
\text { Males represented } 75.9 \% \text { of } \\
\text { MVC injures. } \\
\text { The isolated femoral shaft frac- } \\
\text { tures represented } 70.9 \% \text {, while } \\
\text { femoral shaft fractures with } \\
\text { associated injuries represented } \\
29.1 \% \text {. }\end{array}$ & Western region - Medina & 15 \\
\hline (Alghnam et al., 2020) [41] & $2016-2019$ & $\begin{array}{l}\text { Retrospective } \\
\mathrm{N}=253\end{array}$ & $\begin{array}{l}\text { The proportion of head injury } \\
\text { in following MVC was } 38.3 \% \\
\text { and facial injury was } 34.8 \% \text {. } \\
\text { Male represented } 68.8 \% \text { of the } \\
\text { study population. } \\
\text { The majority of injured children } \\
\text { (53.8\%) were back seated with- } \\
\text { out seatbelts or safety seats } \\
\text { while } 9.1 \% \text { were driving. } \\
\text { The mortality rate was } 2.4 \% \text {. }\end{array}$ & Several regions & 18 \\
\hline
\end{tabular}

unintentional injuries that occurred between 2001 and 2019 in the United States [55]. Likewise, in low- and middle-income countries, male children were more susceptible to injuries than females [53]. This gender disparity can be attributed to the greater risk-taking tendency in males [56]. Thus, gender-specific prevention strategies may help reduce the burden of associated injuries [57].

Although the mortality rate was relatively low, it may reflect the underlying resources for capturing injury data. However, the rate was exceptionally high among more critical cases such as ICU burns (25.3\%) and head injuries (14.7\%), followed by fractures (8.3\%). Correspondingly, a study on childhood mortality in the eastern region showed that half of the deaths (51\%) were attributed to accidents, with male children representing $69 \%$ of the cases [58]. In addition, the autopsy has revealed that head injury was the leading cause of death $(27 \%)$ among the autopsied cases [58]. These are high rates, and national actions need to be undertaken to reduce them.

Primary prevention of injuries provides the best value and return on the outcome. The Child Safety Action Plan (CSAP) in European Union serves as an excellent example for tackling mortality resulting from childhood injuries [59]. This policy was first developed through assessing the situation with government engagement, followed by setting a vision, goals, and objectives, and finally implementing the best evidence-based practices that the government endorsed. 
Table 5 Study characteristics and relevant findings of studies of childhood dental trauma

\begin{tabular}{|c|c|c|c|c|c|}
\hline Author & Timeframe & Study type (sample size) & Relevant findings & Region & STROBE Score \\
\hline (Al-Majed et al., 2001) [42] & 1997 & $\begin{array}{l}\text { Cross-sectional } \\
N=1216 \\
\text { Gender: male }\end{array}$ & $\begin{array}{l}\text { The prevalence of dental trauma } \\
\text { was } 32.8 \% \text { among boys aging } \\
\text { between } 5-6 \text { years and } 34.3 \% \\
\text { among those aged } 12-14 \text { years. }\end{array}$ & Riyadh & 9 \\
\hline (Al-Malik, 2009) [43] & $2005-2006$ & $\begin{array}{l}\text { Cross-sectional } \\
\mathrm{N}=112\end{array}$ & $\begin{array}{l}\text { The prevalence of traumatic oral } \\
\text { injury was higher among males } \\
(70.5 \%, P<0.05) \text {, and age between } \\
9-11 \text { years } \\
\text { Fall was the most common cause of } \\
\text { traumatic oral injuries }(68 \%) \\
\text { Injuries where most likely to occur } \\
\text { in the street in males }(69.6 \%) \text { and at } \\
\text { home }(60.6 \%) \text { in females. }\end{array}$ & Western region - Jeddah & 13 \\
\hline (Gupta et al., 2018) [44] & 2016 & $\begin{array}{l}\text { Cross-sectional } \\
\mathrm{N}=868\end{array}$ & $\begin{array}{l}\text { The prevalence of traumatic dental } \\
\text { injury was } 9.79 \% \text { with fall being the } \\
\text { most common cause }(62.4 \%) \\
\text { Traumatic dental injuries were more } \\
\text { common among male with a male } \\
\text { female ratio of 1.6:1. }\end{array}$ & Southern region - Jazan & 13 \\
\hline (Al-Ansari \& Nazir, 2020) [45] & 2020 & $\begin{array}{l}\text { Cross-sectional } \\
N=258 \\
\text { Gender: male }\end{array}$ & $\begin{array}{l}\text { As per a self-reported question- } \\
\text { naire, } 39.5 \% \text { of middle school male } \\
\text { children had experienced dental } \\
\text { trauma whilst only } 20.5 \% \text { received } \\
\text { treatment. } \\
\text { Higher family income was associ- } \\
\text { ated with lower likelihood of dental } \\
\text { trauma (OR: } 0.44, P<0.05 \text { ) and } \\
\text { lower odds of receiving treatment } \\
\text { for dental trauma (OR: } 0.41, P< \\
0.05 \text { ). }\end{array}$ & $\begin{array}{l}\text { Eastern region } \\
\text { Dammam - Alkhobar }\end{array}$ & 17 \\
\hline
\end{tabular}

OR Odds ratio

Our findings have some policy and public health implications, namely supporting the Saudi 2030 vision [60]. One of the pillars of this Vision is to extend life expectancy from 74 to 80 and improve quality of life. Our research describes the magnitude of the problem and highlights the need for intersectoral interventions. As the Vision focuses on preventing health risks, preventive interventions of childhood injuries, namely fall, and MVC need to be implemented. One of the Vision's objectives is to promote traffic safety which could potentially aid in MVC prevention. Another implication is highlighting the need for investing in secondary prevention by dealing with injuries once they occur to reduce their consequences. A recent cross-sectional study found a low level of awareness about first aid to childhood injuries such as burns, drowning, and choking among 39\% of Saudi parents [61]. However, most parents (78\%) were willing to take a first aid class. This reinforces the need to implement sustainable awareness-raising strategies at the family level.

This is the first scoping review of the epidemiology of childhood injuries in Saudi Arabia to the best of our knowledge. However, we acknowledge that our review has several limitations. First, the lack of socioeconomic data may not reflect the variation of the prevalence and the mechanisms of injuries. Second, we were also unable to capture and generalize the age groups due to the missing continuous data and the inconsistency in age group classification across the studies. Third, most studies were retrospective chart review studies which can be more susceptible to bias. There is a significant need for population-based and longitudinal studies to provide more substantial evidence of the burden of injuries on population health of the kingdom. Fourth, except for one study, the primary focus of the included publications was unintentional injuries, which emphasizes the need to extend the current research in Saudi Arabia to nonaccidental childhood injuries. Finally, there was a substantial difference in publication rates across the regions of Saudi Arabia as more than half of the included studies were conducted in the central region-Riyadh, which affects the generalizability of our findings. This can be attributed to the presence of highly equipped trauma centers and research institutions in the region. Clearly, there is a disparity in our ability to capture the true burden in other regions accurately. Therefore, it is crucial to conduct further studies on the prevalence and magnitude of childhood injuries across all regions of Saudi Arabia while maintaining a high-quality research and reporting practices. 
Table 6 Study characteristics and relevant findings of studies of childhood poisoning and toxicological exposure

\begin{tabular}{|c|c|c|c|c|c|}
\hline Author & Timeframe & Study type (sample size) & Relevant findings & Region & STROBE Score \\
\hline (Izuora \& Adeoye, 2001) [46] & $1992-1998$ & $\begin{array}{l}\text { Retrospective } \\
\mathrm{N}=168\end{array}$ & $\begin{array}{l}\text { The majority of accidental poisoning } \\
(63 \%) \text { occurred in children aged } \\
\text { between } 1-3 \text { years. } \\
\text { The most frequently involved sub- } \\
\text { stance was drugs ( } 64.3 \%) \text {. } \\
\text { Most cases (>60\%) were asympto- } \\
\text { matic. } \\
\text { No reported deaths. }\end{array}$ & Eastern region - Hafr Albatin & 12 \\
\hline (Al-Binali et al., 2009) [47] & $1990-1995$ & $\begin{array}{l}\text { Retrospective } \\
\mathrm{N}=72\end{array}$ & $\begin{array}{l}\text { The most common type of corro- } \\
\text { sives was } 5.25 \% \text { hypochlorite }(50 \%) \text {, } \\
\text { followed by kerosene in }(16.7 \%) \text {, and } \\
\text { caustic soda }(12.5 \%) \text {. } \\
\text { No action was taken by parents of } \\
90.2 \% \text { of the cases. } \\
\text { No reported deaths. }\end{array}$ & Southern region - Asir & 10 \\
\hline (Alanazi et al., 2015) [48] & $2009-2011$ & $\begin{array}{l}\text { Retrospective } \\
N=315\end{array}$ & $\begin{array}{l}\text { The majority of child poison } \\
\text { occurred among toddlers ( } 72 \%) \text {. } \\
\text { Most poisoning incidents occurred } \\
\text { in males ( } 59 \%) \text {. } \\
\text { The most frequently involved sub- } \\
\text { stance was drugs ( } 63.2 \%) \text {. } \\
\text { Age was a significant predictor of } \\
\text { hospital admission (OR: } 1.19, P< \\
0.05 \text { ). }\end{array}$ & Riyadh & 17 \\
\hline (Bakhaidar et al., 2015) [49] & $2008-2012$ & $\begin{array}{l}\text { Retrospective } \\
N=129\end{array}$ & $\begin{array}{l}\text { Children under } 12 \text { years represented } \\
44.2 \% \text { chemical poisoning admis- } \\
\text { sions. } \\
\text { More than half of poisoning cases } \\
(54.3 \%) \text { were females. } \\
\text { Accidental poisoning occurred in } \\
92.9 \% \text { of children younger than } 12 \\
\text { years. } \\
\text { No reported deaths. }\end{array}$ & Western region & 15 \\
\hline (Alghadeer et al., 2018) [50] & $2010-2016$ & $\begin{array}{l}\text { Retrospective } \\
N=735\end{array}$ & $\begin{array}{l}\text { The mean age was } 2.7 \text { years. } \\
\text { The most common type of poison- } \\
\text { ing was drugs ( } 70 \%) \text {. } \\
\text { The majority of cases were asymp- } \\
\text { tomatic. }\end{array}$ & Riyadh & 16 \\
\hline (Alanazi et al., 2018) [51] & 2018 & $\begin{array}{l}\text { Cross-sectional } \\
\mathrm{N}=96\end{array}$ & $\begin{array}{l}\text { More than third ( } 35 \% \text { ) of poisoning } \\
\text { cases were between } 4-8 \text { years and } \\
24 \% \text { were younger than } 4 \text { years. } \\
\text { Poisoning injury were most com- } \\
\text { mon in males } 57.3 \% \text { compared to } \\
42.7 \% \text {. } \\
\text { Accidental poisoning occurred in } \\
94.8 \% \text { whereas } 5.2 \% \text { were intended. } \\
\text { The most common cause of poison- } \\
\text { ing was spoiled food } 55.2 \%) \\
\text { The mortality rate was } 3.1 \% \text {. }\end{array}$ & Several regions & 5 \\
\hline (Alruwaili et al., 2019) [52] & $2016-2017$ & $\begin{array}{l}\text { Cross-sectional } \\
N=1035\end{array}$ & $\begin{array}{l}\text { Most of toxicological exposed } \\
\text { children ( } 78.7 \% \text { ) were asympto- } \\
\text { matic and } 47.8 \% \text { did not need an } \\
\text { intervention. } \\
\text { Most exposure incidents ( } 91 \%) \\
\text { occurred in children younger than } \\
6 \text { years with } 62.2 \% \text { of them being } \\
\text { younger than } 3 \text { years. } \\
\text { The most frequently involved } \\
\text { substance class was toxic household } \\
\text { products in children younger than } \\
6 \text { years and pesticides in children } 6 \\
\text { years or older. }\end{array}$ & Riyadh & 15 \\
\hline
\end{tabular}




\section{Conclusions}

This review found that the leading causes and mechanisms of childhood injuries were falls and MVC. Unfortunately, all types of injuries resulted in substantial mortality rates, and there is a definite need for national action to be undertaken to reduce them. Overall, further research should be carried out to capture the determinants of childhood injuries across all regions of Saudi Arabia.

\section{Abbreviations}

CDC: Centers for Disease Control and Prevention; CSAP: Child Safety Action Plan; DALY: Disability-adjusted life years; GBD: Global Burden of Disease; ICU: Intensive Care Unit; MVC: Motor Vehicle Collision; STROBE: Strengthening the Reporting of Observational Studies in Epidemiology; TBSA: Total Body Surface Area; WHO: World Health Organization.

\section{Supplementary Information}

The online version contains supplementary material available at https://doi. org/10.1186/s12887-021-02886-8.

Additional file 1: Supplementary Table 1. Search terms and search limits for all databases.

Additional file 2: Supplementary Table 2. The STROBE assessment of all included studies.

\section{Acknowledgments}

Not applicable.

\section{Authors' contributions}

HA designed the review, abstracted data, participated in screening and assessment of articles and manuscript drafting. SA conceptualized the scoping review, critically reviewed the manuscript, and supervised the project. NA participated in assessment of articles and manuscript drafting. AK, AA and SMA participated in the manuscript critical review. All authors read and approved the final manuscript.

\section{Funding}

No funding was received for this study.

\section{Availability of data and materials}

The study data is available from the corresponding author upon request.

\section{Declarations}

Ethics approval and consent to participate

Not applicable.

\section{Consent for publication}

Not applicable.

\section{Competing interests}

The authors declare that they have no competing interests.

\section{Author details}

${ }^{1}$ Department of Community Health Sciences, College of Applied Medical Sciences, King Saud University, Riyadh, Saudi Arabia. ${ }^{2}$ Biostatistics, Epidemiology and Scientific Computing Department, King Faisal Specialist Hospital and Research Center, Riyadh, Saudi Arabia. ${ }^{3}$ Saudi Public Health Authority, Riyadh, Saudi Arabia. ${ }^{4}$ Population Health Section-King Abdullah International Medical Research Center, King Saud bin Abdulaziz University for Health Sciences, Riyadh, Saudi Arabia.
Received: 6 June 2021 Accepted: 9 September 2021

Published online: 25 September 2021

\section{References}

1. Bustos Córdova E, Cabrales Martínez RG, Cerón Rodríguez M, Naranjo López MY. Epidemiología de lesiones no intencionales en niños: revisión de estadísticas internacionales y nacionales. Bol Med Hosp Infant Mex. 2014;71:68-75.

2. Haagsma JA, Graetz N, Bolliger I, Naghavi M, Higashi H, Mullany EC, et al. The global burden of injury: incidence, mortality, disability-adjusted life years and time trends from the Global Burden of Disease study 2013. Inj Prev. 2016;22(1):3-18.

3. World Health Organization: Child Injuries. Available from: https://www. who.int/violence_injury_prevention/child/injury/en/.

4. Centers for Disease Control and Prevention. Web-based Injury Statistics Query and Reporting System (WISQARS) [Online]. Fatal Injury Reports, Centers for Disease Control and Prevention. 2003. Available from: 2003. Available from: www.cdc.gov/injury/wisqars. 2021 Mar 13.

5. Peden M OK, Ozanne-smith J, Hyder AA., Branche C, Rahman FA, et al. Geneva: World Health Organization; 2008. WHO Guidelines Approved by the Guidelines Review Committee. 2008.

6. Murray CJL, Aravkin AY, Zheng P, Abbafati C, Abbas KM, Abbasi-Kangevari $M$, et al. Global burden of 87 risk factors in 204 countries and territories, 1990-2019: a systematic analysis for the Global Burden of Disease Study 2019. Lancet. 2020;396(10258):1223-49.

7. Dowd MD, Keenan HT, Bratton SL. Epidemiology and prevention of childhood injuries. Crit Care Med. 2002;30(11 Suppl):S385-92.

8. Baker SP, O'Neill B, Ginsburg MJ, Li G. The Injury Fact Book. Second Edition. New York: Oxford University Press; 1992.

9. Mock CN, Abantanga F, Cummings P, Koepsell TD. Incidence and outcome of injury in Ghana: a community-based survey. Bull World Health Organ. 1999;77(12):955-64.

10. Smith GS, Barss P. Unintentional injuries in developing countries: the epidemiology of a neglected problem. Epidemiol Rev. 1991;13:228-66.

11. Tupetz A, Friedman K, Zhao D, Liao H, Isenburg MV, Keating EM, et al. Prevention of childhood unintentional injuries in low- and middle-income countries: A systematic review. PLoS One. 2020;15(12):e0243464.

12. Sethi D, Aldridge E, Rakovac I, Makhija A. Worsening Inequalities in Child Injury Deaths in the WHO European Region. Int J Environ Res Public Health. 2017;14(10):1128.

13. Lao Z, Gifford M, Dalal K. Economic cost of childhood unintentional injuries. Int J Prev Med. 2012;3(5):303-12

14. Tyrovolas S, El Bcheraoui C, Alghnam SA, Alhabib KF, Almadi MAH, Al-Raddadi RM, et al. The burden of disease in Saudi Arabia 1990-2017: results from the Global Burden of Disease Study 2017. Lancet Planetary Health. 2020;4(5):e195-208.

15. Almuneef $M$, Saleheen $H$, AlBuhairan F, Al-Eissa M, Al Muntaser M, Al Alem $\mathrm{H}$, et al. Child mortality in Saudi Arabia:Time for action at all levels. Int J Pediatrics Adolescent Med. 2020. https://doi.org/10.1016/j.ijpam.2020.06. 003.

16. von Elm E, Altman DG, Egger M, Pocock SJ, Gotzsche PC, Vandenbroucke $J$, et al. The Strengthening the Reporting of Observational Studies in Epidemiology (STROBE) statement: guidelines for reporting observational studies. J Clin Epidemiol. 2008;61(4):344-9.

17. Gad A, AL-Eid R, Al-Ansary S, Saeed A b, Kabbash A. Pattern of injuries among children and adolescents in Riyadh, Saudi Arabia: a household survey. J Trop Pediatr. 2011;57(3):179-84.

18. Alhabdan S, Zamakhshary M, AlNaimi M, Mandora H, Alhamdan M, Al-Bedah K, et al. Epidemiology of traumatic head injury in children and adolescents in a major trauma center in Saudi Arabia: implications for injury prevention. Ann Saudi Med. 2013;33(1):52-6.

19. Alanzi A. Fingertip injuries in paediatric patients - experiences at an emergency centre in Saudi Arabia. J Pak Med Assoc. 2013;63(6):675-9.

20. Assiry K, Abdulmutali $\mathrm{H}$, Alqahtani A, Alyahya A, Elawad M. Traumatic Head Injuries in Children: Experience from Asir. KSA: Online Journal of Medicine and Medical Science Research; 2014. 
21. Alnasser A, Othman A, Mobaireek O, Alharthy N, Aljerian N, et al. Epidemiology of pediatric trauma at a tertiary hospital in Riyadh, Saudi Arabia. J Nat Sci Biol Med. 2018;9(2):247-51.

22. Alghnam S, Towhari JA, Al Babtain I, Al Nahdi M, Aldebasi MH, Alyami M, et al. The associations between injury mechanism and extended hospital stay among pediatric patients: findings from a trauma Center in Saudi Arabia. BMC Pediatr. 2019;19(1):177.

23. Al-Qurashi FO, Yousef AA, Aljoudi A, Alzahrani SM, Al-Jawder NY, Al-Ahmar AK, et al. A Review of Nonfatal Drowning in the Pediatric-Age Group: A 10-Year Experience at a University Hospital in Saudi Arabia. Pediatr Emerg Care. 2019;35(11):782-6.

24. Alzamil WM, Alshamlan FT, Alkhaldi HM, Almubaiyd AM, Alsaif AA, Alhamad JR, et al. Causes of blindness in a pediatric age group at a tertiary healthcare center in the eastern province of Saudi Arabia. Saudi Med J. 2019;40(10):1063-6.

25. AlAteeq MA, Alsulayhim AK, AlHargan F, AlSamaani IS, Alyousef M, AIDossari A. Morbidity Patterns of Non-Traffic Unintentional Injuries Among the Pediatric Age Group Attending the Emergency Department at King Abdul-Aziz Medical City, Riyadh, Saudi Arabia. Cureus. 2020;12(7):e9258.

26. Alkhamis KN, Abdulkader RS. Assessment of unintentional childhood injuries and associated factors in the pediatric clinics of a tertiary care hospital in Riyadh, Saudi Arabia. J Family Commun Med. 2020;27(3):168-77.

27. Al-Sarheed S, Alwatban J, Alkhaibary A, Babgi Y, Al-Mohamadi W, Masuadi EM, et al. Cervical spine clearance in unconscious pediatric trauma patients: a level I trauma center experience. Childs Nerv Syst. 2020;36(4):811-7.

28. Alomran A, Bubshait D, Sadat-Ali M. Epidemiology of Pediatric Fractures and Dislocations: Analysis of In-Patients. Bahrain Med Bull. 2012;34(4).

29. Al-Habib A, Alaqeel A, Marwa I, Almohammadi M, Al Shalaan H, AlEissa $S$, et al. Causes and patterns of spine trauma in children and adolescents in Saudi Arabia: implications for injury prevention. Ann Saudi Med. 2014;34(1):31-7.

30. Al-Jasser FS, Mandil AM, Al-Nafissi AM, Al-Ghamdi HA, Al-Qattan MM. Epidemiology of pediatric hand fractures presenting to a university hospital in Central Saudi Arabia. Saudi Med J. 2015;36(5):587-92.

31. Umerani MS, Abbas A, Aziz F, Shahid R, Ali F, Rizvi RK. Pediatric Extradural Hematoma: Clinical Assessment Using King's Outcome Scale for Childhood Head Injury. Asian J Neurosurg. 2018;13(3):681-4.

32. Jawadi AH, Benmeakel M, Alkathiri M, Almuneef MA, Philip W, Almuntaser M. Characteristics of Nonaccidental Fractures in Abused Children in Riyadh, Saudi Arabia. Saudi J Med Med Sci. 2019;7(1):9-15.

33. Priyadarshini S, Kumar P. Epidemiology and profile of pediatric burns- a retrospective review. Soc Wound Care Res. 2015;8:29-33.

34. Alharthy N, Al Mutairi M, AlQueflie S, Nefesa AB, Manie NB, Nafesa SB, et al. Pattern of burns identified in the Pediatrics Emergency Department at King Abdul-Aziz Medical City: Riyadh. J Nat Sci Biol Med. 2016;7(1):16-21.

35. Alturki N, Alkahtani M, Daghistani M, Alyafi T, Khairy S, Ashi M, et al. Incidence and risk factors for deep vein thrombosis among pediatric burn patients. Burns. 2019;45(3):560-6.

36. Akkam AY, Joarder A, Cruz-Marcelino N, Mitra B, Alshehri S, Almazroua F. Epidemiology of pediatric patients admitted to a burns ICU in Saudi Arabia. Burns Open. 2020;4(3):90-3.

37. Mater ME, Yamani AE, Aljuffri AA, Binladen SA. Epidemiology of burnrelated infections in the largest burn unit in Saudi Arabia. Saudi Med J. 2020;41(7):726-32.

38. Crankson SJ. Motor vehicle injuries in childhood: a hospital-based study in Saudi Arabia. Pediatr Surg Int. 2006;22(8):641-5.

39. Al-Jazaeri A, Zamakhshary M, Al-Omair A, Al-Haddab Y, Al-Jarallah O, Al-Qahtani R. The role of seating position in determining the injury pattern among unrestrained children involved in motor vehicle collisions presenting to a level I trauma center. Ann Saudi Med. 2012;32(5):502-6.

40. Mohmmedthani T, Alfraidi T, Sonbol A, Almulla A, Hetaimish B, Alrashidi Y. Prevalence of femoral shaft fracture and associated injuries among children after road traffic accidents in a Saudi Arabian trauma center. $J$ Musculoskeletal Surg Res. 2018;2:66-9.

41. Alghnam S, Jastaniah E, Alwahaibi W, Albabtain IT, Alqublan S, Bajwaiber $\mathrm{M}$, et al. The prevalence of head and facial injuries among children in Saudi Arabia following road traffic crashes. Ann Saudi Med. 2020:40(5):417-24.
42. Al-Majed I, Murray JJ, Maguire A. Prevalence of dental trauma in 5-6- and 12-14-year-old boys in Riyadh, Saudi Arabia. Dent Traumatol. 2001;17(4):153-8.

43. Al-Malik M. Oral injuries in children attending a hospital in Saudi Arabia. J Maxillofac Oral Surg. 2009:8(1):34-9.

44. Gupta M, Apathsakayan R, Lnu A. Traumatic Injuries to the Anterior Teeth among Children of Jazan, Kingdom of Saudi Arabia: A Screening Study. World J Dentistry. 2018;9(3):192-6.

45. Al-Ansari A, Nazir M. Prevalence of Dental Trauma and Receipt of Its Treatment among Male School Children in the Eastern Province of Saudi Arabia. Sci World J. 2020;2020:7321873.

46. Izuora Gl, Adeoye A. A seven-year review of accidental poisoning in children at a Military Hospital in Hafr Al Batin, Saudi Arabia. Ann Saudi Med. 2001;21(1-2):13-5.

47. Al-Binali AM, Al-Shehri MA, Abdelmoneim I, Shomrani AS, Al-Fifi SH. Pattern of corrosive ingestion in southwestern Saudi Arabia. Saudi $J$ Gastroenterol. 2009;15(1):15-7.

48. Alanazi M, Al-jerisay M, Al-assiri M, Afeesh L, Alhammad F, Salam M. Hospital Performance Indicators and Their Associated Factors in Acute Child Poisoning at a Single Poison Center, Central Saudi Arabia. Medicine. 2015;94(25):e2399.

49. Bakhaidar M, Jan S, Farahat F, Attar A, Alsaywid B, Abuznadah W. Pattern of drug overdose and chemical poisoning among patients attending an emergency department, western Saudi Arabia. J Community Health. 2015:40(1):57-61.

50. Alghadeer S, Alrohaimi M, Althiban A, Kalagi NA, Balkhi B, Khan AA. The patterns of children poisoning cases in community teaching hospital in Riyadh, Saudi Arabia. Saudi Pharm J. 2018;26(1):93-7.

51. Alanazi M, Alshammari T, Alshehri M, Alaradi A, Alshammari T, Alsagre S, et al. Futures and the outcome of treatment of poisoned children and adolescents admitted to emergency units in different areas of Saudi Arabia. Egypt J Hospital Med. 2018;73(2):5970-975.

52. Alruwaili ND, Halimeh B, Al-Omar M, Alhatali B, Sabie Il, Alsaqoub M. An epidemiological snapshot of toxicological exposure in children 12 years of age and younger in Riyadh. Ann Saudi Med. 2019;39(4):229-35.

53. He S, Lunnen JC, Puvanachandra P, Amar S, Zia N, Hyder AA. Global childhood unintentional injury study: multisite surveillance data. Am J Public Health. 2014;104(3):e79-84.

54. Alsanea M, Masuadi E, Hazwani T. Use of child restraint system and patterns of child transportation in Riyadh, Saudi Arabia. PLoS One. 2018;13(1):e0190471.

55. Centers for Disease Control and Prevention. Web-based Injury Statistics Query and Reporting System (WISQARS) [Online]. (2003). Nonfatal Injury Reports, Centers for Disease Control and Prevention (producer). Available from: 2003 [Available from: www.cdc.gov/injury/wisqars. 2021 Mar 13].

56. Byrnes JP, Miller DC, Schafer WD. Gender differences in risk taking: A meta-analysis. Psychol Bull. 1999;125(3):367-83.

57. Sorenson SB. Gender disparities in injury mortality: consistent, persistent, and larger than you'd think. Am J Public Health. 2011;101(Suppl 1):S353-8.

58. Alsaif DM, Almadani OM, Almoghannam S, Hamdi D, Al-Farayedhi MA, Kharosha MA. Child Fatalities in Dammam: A Call for Child Fatality Reviews in Arab Countries. J Forensic Sci. 2018;63(4):1171-5.

59. MacKey M, Vincenten J. Action Planning for Child Safety: A Strategic and Coordinated Approach to Reducing the Number One Cause of Death for Children in Europe. Amsterdam, The Netherlands: Europe Child Safety Alliance, Eurosafe; 2007.

60. Vision2030.gov.sa. 2021. National Transformation Program / Saudi Vision 2030. [online] Available at: https://www.vision2030.gov.sa/en/programs/ NTP [Accessed 14 March 2021].

61. Habeeb KA, Alarfaj G. Saudi parents awareness regarding burn, choking, and drowning first aid in children. J Family Med Prim Care. 2020;9(3):1370-5.

\section{Publisher's Note}

Springer Nature remains neutral with regard to jurisdictional claims in published maps and institutional affiliations. 